\title{
Studies in the Physiology of Parasitism. VII. Infection of Berberis vulgaris by Sporidia of Puccinia graminis.
}

\author{
$\mathrm{BY}$
}

W. L. WATERHOUSE, B.Sc. (AGR.),

Walter and Eliza Hall Agriculture Research Fellow of the University of Sidney.

(From the Department of Plant Physiology and Pathology, Imperial College of Science and Technology, London.)

With nineteen Figures in the Text.

GOOD deal of attention has of late been paid to the mode of infection of host plants by certain fungi. Blackman and Welsford (1) showed that in the case of Botrytis cinerea the entry of the parasite was not brought about by the dissolution of the cuticle of the host, as previous workers had supposed, but was due to the mechanical pressure exerted by the germ tube. Dey (2), working with Colletotrichum lindemuthianum, obtained similar results. The previous work bearing on the subject of cuticular penetration is referred to and summarized in these two papers and need not be referred to here.

The present investigation was carried out to determine whether in such a widely different form as Puccinia graminis, Pers. entry into the host was brought about in the same way.

The mode of infection of the wheat plant by uredospores of $P$.graminis through the stomata has already been carefully worked out (3). This work followed on a similar investigation by Marshall Ward dealing with the related form $P$. dispersa, Erikss. (4). An investigation of the entry into the host of the aecidiospores and uredospores of a number of other rusts was carried out by Miss Gibson (5). Little, however, appears to have been done in connexion with the details of sporidial infection in any rust fungus. Eriksson (6) refers to the mode of entry of the sporidia of P. Malvacearum into the hollyhock in the following terms: "Wahrscheinlich infolge einer auflösenden Einwirkung des Körpers selbst auf die, Epidermiswand bildet sich an dem Kontaktpünktchen ein sehr feines, kaum sichtbares Loch, durch das sich der Inhalt des Körpers hineinergiesst' (p. 75).

[Annals of Botany, Vol. XXXV. No. CXL. October, I921.] 


\section{Methods.}

In April I920 rusted wheat stubble was collected from a clover field at Milton in Pembrokeshire. It comprised sheath and stem, very badly rusted with teleutosori of $P$.graminis, of the crop that had been harvested in I9I9. During the winter it had of course been fully exposed to the weather. The teleutospores proved viable. This was expected, for sprouting barberry hedges in the vicinity were at the time showing the aecidial stage of the rust. A portion of the straw was kept at ordinary laboratory temperature and a portion in cold storage at a temperature a little above freezing-point. The former gave excellent germinations up to June, and then, as the spores germinated less abundantly, the material that had been kept cool was used. Up to the end of July the germination of these teleutospores was still very good and the sporidia remained capable of infecting the barberry.

To obtain sporidia for study, small pieces of the washed straw containing teleutosori were placed in hanging drops of water on cover-slips with the teleutosori facing downwards. These were supported on rings over sterile slides on which were placed drops of sterile tap-water, of very dilute turnipjuice, or of barberry extract. The latter was prepared by boiling $50 \mathrm{grm}$. of barberry shoots in 1,000 c.c. of water for half an hour, filtering, and sterilizing. These slides were kept in a moist chamber at laboratory temperature. It was found that better results were obtained by using complete sori in this way than by using scrapings of the sori, giving separated teleutospores. The sporidia, formed in the moist atmosphere of the hanging drop (7), fell on to the liquid on the slide and germinated readily. These cultures were contaminated with bacteria and other organisms which spoiled the cultures after about three days. Numerous attempts to grow the sporidia on agar media failed for this reason.

For demonstrating the presence of a mucilaginous sheath, dilute aqueous gentian violet gave better results than Indian ink or collargol. This investment was best seen in the germinations in dilute turnip-juice. Germinating sporidia were also fixed and stained with picro-nigrosin, or fixed in Flemming's fluid and stained in iron-alum-haematoxylin and the triple combination, in order to observe the nuclear details.

For infection work, plants of Berberis vulgaris in pots were obtained and placed in a greenhouse. They were pruned back heavily and the young developing shoots were used for infections. Cut shoots placed in water in sterile glass jars loosely plugged with cotton-wool were tried, but abandoned in favour of shoots still attached to the plant. The shoots were well watered with a fine spray, and then small pieces of the rusted straw, which had been thoroughly washed and then soaked for half an hour in sterile water were, placed on the upper surface of the young leaves. 
The infected shoots were then enclosed in glass or mica cylinders plugged with cotton-wool. Better germinations and more abundant infections were obtained in this way than by sowing teleutospores on the leaves, although infections were obtained by the latter means. Attempts to get infection of mature leaves invariably failed.

Small pieces of the infected leaves were fixed at intervals in acetic alcohol (absolute alcohol three parts, glacial acetic acid one part), and in Flemming's strong solution diluted with an equal volume of water. Both gave good results. The material was embedded in the usual way and was cut into sections $4 \mu$ thick. In the clearing process, satisfactory results were obtained from the cedar-wood oil method, in which the dehydrated material was placed in absolute alcohol floating on cedar-wood oil, whence it gradually passed into the latter liquid under the action of gravity.

For demonstrating the early stages of infection the best details were given by iron-alum-haematoxylin followed by Sudan III. Such sections mounted in glycerin jelly showed the cuticle very sharply stained. Scharlach red and Congo red in place of the Sudan III gave almost as good results. Sections stained with Congo red alone and mounted in euparal also showed up well. For the latter stages of infection, the safranin-gentian violetorange $\mathrm{G}$ combination gave the best results.

\section{OBSERVATIONS.}

Germinations on the slide. Germination of the teleutospores was rapid. Promycelia were to be seen after 5 to 6 hours and sporidia were obtained on the slide after I 2 to 15 hours. These at once germinated by pushing out a germ tube (Fig. I); sometimes two (Fig. 2) or even three (Fig. 3) such tubes were produced. It was early found that the germinating sporidia adhered readily to the slide and could be stained, washed, \&c., without loss. The adhesion is due to the fact that the germ tubes possess a mucilaginous sheath similar to that of Botrytis cinerea. This stains faintly with dilute aqueous gentian violet. At the edges of the sheath, at a distance from the main wall of the germ tube, aggregations of particles further emphasize the presence of the sheath (Figs. I, 2, and 3). The germ tube may continue to elongate, and becomes septate ; in one case it attained a length of over I mm. Frequently, after elongating slightly, the germ tube swells into a vesicle (Figs. 4 and 5 ). In some cases the vesicle was large and in contact with the glass slide and was therefore of the nature of an appressorium; around such an appressorium a mucilaginous investment may or may not be observed (Fig. 5). From the vesicle may arise a second germ tube (Fig. 6). It was generally found that the production of long germ tubes was most frequent when the sporidia were in water. In the nutrient media the production of vesicles was more common, and in the barberry extract these vesicles were often very irregular in shape. 
560 Waterhouse.-Studies in the Physiology of Parasitism. VII.

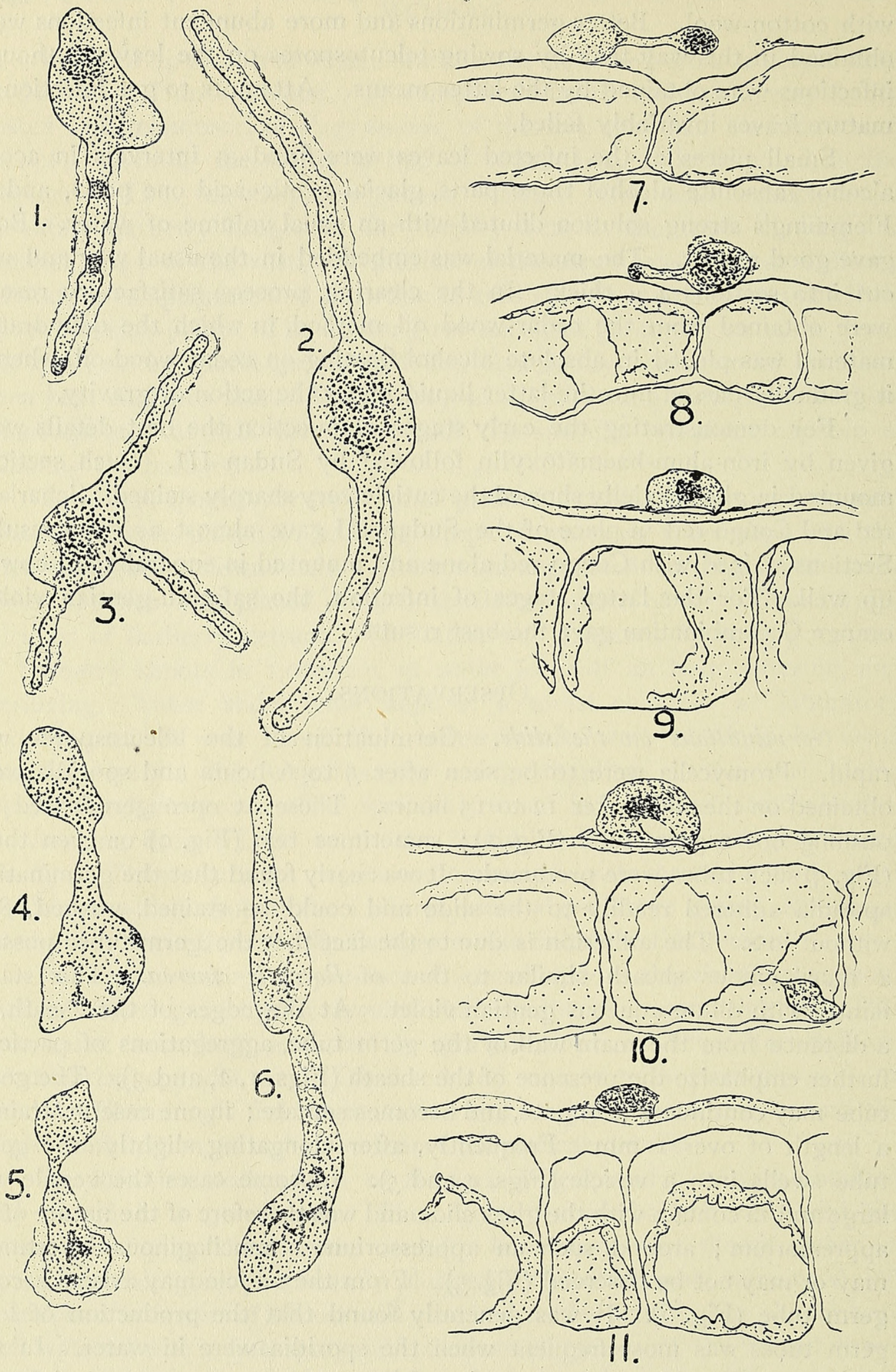

FIGS. I-I I. 
When the germinated sporidia are fixed and stained the remnants of the mucilaginous covering appear as irregular threads and granules (Figs. 7, II, I6). Frequently masses of sporidia adhering together were observed, both in the germinations on the slide and on the barberry leaf. It was not possible to trace any transition from a narrow well-defined wall to a wide indefinite gelatinous investment as described for Botrytis cinerea (1, Fig. 3).

Penetration of the host. Sporidia were observed to have penetrated into the epidermal cells of the barberry leaf in 20 hours. In fixed material, sporidia were seen closely adherent to the leaf surface I7 hours after the teleutosori had been placed on the leaf. No mucilaginous sheath was demonstrated in the case of ungerminated sporidia, but it is possible that a certain amount of gelatinization of the spore wall may take place, anchoring the sporidium to the cuticle. Irregular threads and granules are commonly seen in the immediate neighbourhood of the sporidia and may represent the remains of this mucilage.

On the leaf, germination may result in the production of a definite germ tube. This may develop quickly into a vesicle (Fig. 7), or may grow on for some distance before it reaches the cuticle (Fig. 8) and becomes closely adpressed to the surface. In other cases the germ tube is seen to ramify and grow over the surface for a considerable distance without forming an appressorium.

Instead of producing a definite germ tube, it frequently happens that from the end of the sporidium a short beak-like infection hypha is put out (Fig. 9) which presses closely on the cuticle and may produce a slight indentation in it (Fig. IO). In some cases the growth of the beak-like infection hypha forces the end of the sporidium away from the leaf surface (Fig. II); the tip of this hypha is densely protoplasmic. The hypha then produces an extremely fine style-like structure which penetrates the wall of the epidermal cell (Figs. I3 and 14). In appearance and in its size relative to the body of the sporidium, it reminds one of the proboscis of an insect. This style is pushed through the cuticle and underlying cellulose layers of the epidermal wall (Figs. 13, I4, and 15). A very careful study of the cuticle at the point of entry was made, but no swelling or any sign of alteration in its staining properties could be detected. This penetration of the wall by the stylar outgrowth is rendered possible by the firm adhesion to the cuticular surface which results from the mucilaginous investment of the germ tube. It therefore seems clear that the penetration of the cuticle is brought about mechanically by the pressure exerted by the style-like apex of the infection hypha. No alteration in the nuclei, when these were present in the epidermal cells, or in the cellulose layers underlying the cuticle, could in any case be detected at this stage.

In the barberry leaf, no stomata are present in the upper surface of the leaf, so that entrance into the host always takes place by puncture of the 
cuticle. A parallel series of infections with Puccinia Malvacearum, Mont., was made on leaves of hollyhock, in which stomata are present on the upper surface of the leaf. Eriksson $(6$, p. 75$)$ states that in no case was he able to observe the entry of a germ tube through a stoma. In one case the beak-like projection of a germinating sporidium was found inserted into a stomatal pore, although, in agreement with Eriksson, the mode of entry was by a penetration of the cuticle in all other cases.

After penetrating the epidermal wall, the tip of the infection hypha at once begins to swell (Fig. I6). The swelling enlarges and becomes an elongated vesicle (Fig. I7), which branches (Fig. I9) and gives rise to the uninucleate mycelium which invades the host tissue.

In conclusion, the author wishes to express to Professor V. H. Blackman his gratitude for helpful advice and criticism; also to Dr. S. G. Paine, and Mr. J. F. Dastur, of India, for help in connexion with the work.

\section{SUMmary.}

The infection of Berberis vulgaris by the sporidia of Puccinia graminis has been studied.

In the germinating sporidia, a mucilaginous investment of the germ tube can be shown to be present.

Penetration of the cuticle is brought about by means of a very fine style-like infection hypha, which may be put out either from the end of a definite germ tube or from a short beak-like outgrowth of the sporidium.

There is no evidence of any chemical action upon the cuticle. The puncture of the cuticle appears to be brought about solely by the mechanical pressure exerted by the infection hypha as it develops from the germinating sporidium or germ tube. The sporidial beak or germ tube from which the infecting style grows is firmly fixed to the leaf surface by means of a mucilaginous investment.

As soon as the infection style has penetrated through the epidermal wall it swells into a vesicle from which the mycelium arises.

The entry of the parasite causes at first no visible alteration of the cell contents of the host plant.

\section{REFERENCES.}

1. Blackman, V. H., and Welsford, E. J. (1916): Studies in the Physiology of Parasitism. II. Infection by Botrytis cinerea. Ann. Bot., xxx. 389 .

2. Dey, P. K. (1919): Studies in the Physiology of Parasitism. V. Infection by Colletotrichum lindemuthianum. Ibid., xxxiii. 305 .

3. Evans, I. B. Pole (1907) : The Cereal Rusts. I. Development of their Uredo mycelia. Ibid., xxi. $44 \mathrm{I}$. 
4. Ward, H. Marshall (1903): On the Histology of Uredo dispersa, Erikss., and the 'Mycoplasma Hypothesis'. Phil. Trans. Roy. Soc. Lond., B, cxcvi, p. 29.

5. Gibson, C. M. (1904): Notes on Infection Experiments with Various Uredineae. New Phytol., iii. 184 .

6. Eriksson, J. (1911): Der Malvenrost.

7. Blackman, V. H. (1903): On the Conditions of Teleutospore Germination and of Sporidia Formation in the Uredineae. New Phytol., ii. Io.

\section{EXPLANATION OF FIGURES.}

The host tissue in every case is that of the leaf of Berberis vulgaris.

All figures were drawn with the camera lucida under a Koristka $\frac{1}{15}$-inch semi-apochromatic oilimmersion objective and No. 8 eyepiece, except Figs. I-3, which were drawn under a Leitz $\frac{1}{12}$-inch oil-immersion objective and No. 12 eyepiece.

Fig. I. Sporidium germinating on slide and producing a single germ tube with a mucilaginous sheath. Drawn from living material stained with weak aqueous gentian violet. $\times 2,000$.

Fig. 2. Germinating sporidium producing two germ tubes with mucilaginous sheaths; material as in Fig. 1. $\times 2,000$.

Fig. 3. Germinating sporidium producing three germ tubes: material as in Fig. I. $\times 2,000$.

Fig. 4. Germinating sporidium producing a vesicle; material as in Fig. $1 . \times 1,560$.

Fig. 5. Germinating sporidium producing vesicle with a mucilaginous investment; material as in Fig. I. $\times 1,560$.

Fig. 6. Sporidium germinating and producing a vesicle which is developing a germ tube above; material as in Fig. I. $\times 1,560$.

Fig. 7. Sporidium germinating on barberry leaf and producing a vesicle. $\times 1,560$.

Fig. 8. Sporidium on barberry leaf, germinating with production of a simple germ tube, the tip of which is adpressed to the surface of the leaf. $\times 1,560$.

Fig. 9. Sporidium attached to leaf and producing a beak-like protuberance at one end. $\times \mathrm{I}, 560$.

Fig. Io. Beak-like projection of sporidium producing an indentation of the cuticle. $\times$ I,560.

Fig. I1. Outgrowth from sporidium pressing upon the cuticle and forcing up the end of the sporidium. $\times 1,560$.

Fig. I 2. Sporidium producing a longer beak-like process with its densely protoplasmic tip closely pressed against the cuticle. $\times 1,560$.

Fig. I3. Sporidium producing a style-like infection hypha which has pierced the cuticle. The section is cut in such a way that the actual connexion between the style and the sporidium is not shown. $\times \mathbf{I}, 560$.

Fig. I4. Sporidium showing the infection hypha which has penetrated the whole thickness of the epidermal wall. $\times \mathrm{I}, 560$.

Fig. I5. Infection hypha, developed from a germ tube, which has pierced the cuticle. $\times$ I,560.

Fig. 16. Germination of sporidium has led to the formation of irregular vesicles. An infection style has penetrated the epidermal cell and is beginning to swell at the tip. $\times$ I,560.

Fig. I7. A later stage of penetration. The vesicle in the epidermal cell has increased in size. $\times 1,560$.

Fig. I8. Larger vesicle showing three nuclei. $\times 1,560$.

Fig. 19. Two epidermal cells which have been invaded, showing the branching of the mycelium arising from the infection vesicle. The shrivelled remains of the germinated sporidia are to be seen on the leaf surface. $\times I, 560$. 


\section{$2 \mathrm{BHL}$ Biodiversity Heritage Library}

Waterhouse, Walter Lawry. 1921. "Studies in the physiology of parasitism. VII. Infection of Berberis vulgaris by sporidia of Puccinia graminis." Annals of botany 35, 557-564. https://doi.org/10.1093/oxfordjournals.aob.a089776.

View This Item Online: https://www.biodiversitylibrary.org/item/235780

DOI: https://doi.org/10.1093/oxfordjournals.aob.a089776

Permalink: https://www.biodiversitylibrary.org/partpdf/319019

\section{Holding Institution}

Smithsonian Libraries

\section{Sponsored by}

Biodiversity Heritage Library

\section{Copyright \& Reuse}

Copyright Status: Not in copyright. The BHL knows of no copyright restrictions on this item.

This document was created from content at the Biodiversity Heritage Library, the world's largest open access digital library for biodiversity literature and archives. Visit BHL at https://www.biodiversitylibrary.org. 